\title{
Pengaruh Investment Opportunity Set dan Ukuran Perusahaan terhadap Deviden Kas
}

\author{
Nanu Hasanuh ${ }^{1}$ \\ 1) dosen Universitas Singaperbangsa Karawang, email :nanu alvaro@yahoo.co.id
}

\section{ARTICLES \\ INFORMATION}

ABSTRACT

\section{JURNAL SEKURITAS (Saham, Ekonomi, \\ Keuangan dan Investasi) \\ Vol.3, No.1, September 2019 \\ Halaman : 33- 44 \\ @ () LPPM \& Prodi Manajemen \\ UNVERSITAS PAMULANG \\ ISSN (online) : 2581-2777
ISSN (print) $: 2581-2696$}

\section{Keyword :}

Deviden Kas, Investment Opportunity Set, Ukuran Perusahaan.

\section{JEL Classification : \\ C33, G21, G24, N15, N25}

\section{Contact Author: \\ PRODI MANAJEMEN UNPAM \\ JL.Surya Kencana No.1 Pamulang \\ Tangerang Selatan-Banten \\ Telp. (021) 7412506 , Fax (021) 7412491 Email: \\ jurnalfinance.unpam@gmail.com}

sekuritas@unpam.ac.id

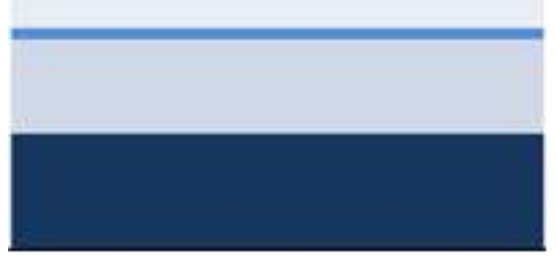

Penelitian ini untuk menguji pengaruh investment opportunity set (IOS) dan ukuran perusahaan terhadap deviden kas. Populasi dalam penelitian ini adalah semua perusahaan indeks LQ45. Teknik pengumpulan data menggunakan teknik purposive sampling. Sampel dalam penelitian ini sebanyak 15 perusahaan dengan periode antara 2015-2017.

Analisis data menggunakan analisis regresi berganda dengan bantuan SPSS Versi 22. Hasil penelitian ini mengindikasikan bahwa secara parsial investment opportunity set (IOS) berpengaruh positif terhadap deviden kas. Perusahaan terindeks dengan LQ45 adalah perusahaan yang terus tumbuh, IOS tinggi, tapi tetap memberikan pembayaran deviden kas tinggi. Sebaliknya variabel ukuran perusahaan tidak berpengaruh terhadap deviden kas. Perusahaan-perusahaan LQ45 adalah perusahaan yang dipandang baik dengan aset yang besar, menganggap bahwa pembayaran deviden kas adalah hal wajar, sehingga ketika tingkat aset naik atau pun turun, deviden kas tetap dibayarkan.

This study is to examine the effect of investment opportunity set (IOS) and company size on cash dividends. The population in this study are all LQ45 index companies. Data collection techniques using purposive sampling technique. The sample in this study were 15 companies with a period between 2015-2017. Data analysis using multiple regression analysis with the help of SPSS Version 22. The results of this study indicate that partially investment opportunity set (IOS) has a positive effect on cash dividends. LQ45 indexed companies are companies that continue to grow, IOS is high, but still provides high cash dividend payments. Conversely, the company's size variable does not affect cash dividends. LQ45 companies are wellregarded companies with large assets, assuming that cash dividend payments are reasonable, so that when the level of assets rises or falls, cash dividends are still paid 


\section{A. PENDAHULUAN}

\section{Latar Belakang}

Perusahaan membutuhkan dana untuk operasionalnya. Dana yang didapat bisa dari dalam maupun luar perusahaan. Dana dari luar perusahaan didapat dari kreditur dan investor. Ketika perusahaan memutuskan mendapatkan dana dari investor, kedepannya perusahaan akan memberikan bagian laba kepada para investor. Sebaliknya bagi para investor dalam pengambilan keputusan investasi mempertimbangkan tingkat pengembalian. Sukamulja (2017) investor memastikan bahwa keputusan investasi yang diambilnya harus memberikan return. Berbicara return yang baik dan tinggi, perusahaanperusahaan di Indonesia selalu memberikan return yang tinggi. Dalam Sukamulja (2017) Indonesia mempunyai return rata-rata tertinggi tahunan dibanding dengan delapan pasar modal lainnya, yaitu sebesar $12,705 \%$, sebaliknya Jepang menempati urutan terakhir. Ini menunjukkan bahwa Indonesia menjadi tempat yang menarik untuk investasi.

Hartono (2013), perusahaan yang mendapatkan laba, dapat ditahan sebagai sumber dana internal (retained earning) atau dibagikan dalam bentuk deviden. Arus deviden dapat dianggap sebagai arus kas yang diterima oleh investor. Bagi investor deviden kas merupakan salah satu pengembalian investasi dalam sebuah perusahaan. Investor percaya bahwa perusahaan yang membayar deviden kas adalah perusahaan dengan kondisi keuangan yang baik. Sama dengan Kristanti (2013) dalam hubungannya dengan pendapatan dividen, para investor umumnya menginginkan pembagian dividen yang relatif stabil dan dalam bentuk tunai. Hal ini dapat meningkatkan kepercayaan investor terhadap perusahaan sehingga mengurangi ketidakpastian investor dalam menanamkan dananya kedalam perusahaan. Darmadji (2012) deviden merupakan salah satu daya tarik bagi investor dengan orientasi jangka panjang. Dhestiani et al (2018), perusahaan yang mempunyai kemampuan untuk membayar dividen akan dinilai sebagai perusahaan yang memperoleh keuntungan.

Namun keputusan membagi dividen merupakan suatu masalah yang sering dihadapi oleh perusahaan. Laba ditahan diperlukan untuk memperluas usaha dalam rangka pertumbuhan perusahaan. Jika hal tersebut dilakukan, maka jumlah pembayaran deviden kepada investor kecil. Semakin besar pembayaran deviden kepada investor, semakin sedikit saldo laba sehingga mengakibatkan terhambatnya pertumbuhan perusahaan. Pembayaran deviden mengurangi dana untuk ekspansi usaha sehingga menghambat pertumbuhan perusahaan. Kondisi seperti ini diperlukan kebijakan deviden oleh manajemen secara baik karena menyangkut kepentingan investor mendapatkan dananya dan kepentingan manajemen memperluas usahanya. Menurut Sari, Ni Luh Putu Puspita dan I Ketut Budiarta (2016), pertimbangan dalam membuat kebijakan dividen menjadi semakin rumit apabila mengakomodasi kepentingan berbagai pihak. Kondisi ini dipandang sebagai konflik keagenan yang menimbulkan biaya keagenan. Biaya keagenan dapat diminimalisir dengan mekanisme pengawasan yang tepat, salah satunya adalah dengan membuat kebijakan deviden yang tepat.

Sarmento et al (2014), menyatakan bahwa manajemen harus mengatur kebijakan deviden yang bertujuan untuk memaksimalisasi kesejahteraan pemilik saham serta menyediakan keuangan untuk pertumbuhan perusahaan. Ardyatama (2018), kebijakan dividen yang optimal adalah kebijakan dividen yang bisa menciptakan keseimbangan di antara dividen saat ini dan pertumbuhan di masa mendatang yang bisa memaksimumkan harga saham perusahaan. Menurut Hartono (2013) pertumbuhan perusahaan menunjukkan investment opportunity set (IOS) atau set kesempatan investasi dimasa datang. Masih menurutnya perusahaan yang bertumbuh mempunyai rasio lebih besar dari nilai satu yang berarti pasar percaya bahwa nilai pasar perusahaan tersebut lebih besar dari nilai bukunya. Sama dengan pendapat Kristanti et al (2013) menyatakan bahwa IOS merupakan nilai perusahaan yang besarnya tergantung pada pengeluaran-pengeluaran 
yang ditetapkan manajemen di masa yang akan datang, yang pada saat ini merupakan pilihan-pilihan investasi yang diharapkan akan menghasilkan return yang lebih besar.

Ukuran perusahaan juga menentukan besarnya deviden tunai yang akan dibayarkan karena semakin besar ukuran perusahaan maka omset yang dihasilkan juga akan semakin tinggi dan menyebabkan laba yang dihasilkan tinggi, jika laba tinggi maka deviden yang dibagikan juga semakin tinggi (Lopolusi dalam Dewi ; 2016).

Kebijakan dividen menjadi menarik untuk diteliti karena dividend policy berperan dalam mengendalikan konflik keagenan. Banyak penelitian yang sudah dilakukan terkait pengaruh IOS terhadap deviden kas. Sari, Ni Luh Putu Puspita dan I Ketut Budiarta (2016), dan Martazela, Ayu et al (2013), melakukan penelitian pengaruh IOS terhadap deviden kas dan hasilnya adalah IOS berpengaruh positif terhadap kebijakan deviden kas. Sementara Kristanti, Farida Titik dan Fitrianingsih (2013), dan Ramadhan, Wiby Aqlia (2016) melakukan penelitian pengaruh IOS terhadap deviden kas. Hasil penelitian mereka IOS berpengaruh negatif terhadap deviden kas. Sebaliknya hasil penelitian Sarmento et al (2014), mengungkapkan bahwa IOS tidak berpengaruh terhadap deviden kas.

Sementara penelitian terkait pengaruh ukuran perusahaan terhadap deviden kas yang telah dilakukan Nurhayati, Mafizatun (2013), Dewi, Dian Masita (2016), Herlambang et al (2017). Hasil penelitian mereka adalah ukuran perusahaan berpengaruh negatif terhadap deviden kas. Sebaliknya hasil penelitian Baharianti, Septi (2018) menghasilkan penelitian ukuran perusahaan tidak berpengaruh terhadap deviden kas.

Hasil penelitian sebelumnya tidak konsisten dan penjelasan yang bertentangan dengan hasilnya, maka memotivasi peneliti untuk melakukan penelitian kembali tentang kebijakan deviden kas. Penelitian ini dilakukan terhadap perusahaan LQ 45 dengan periode 2015-2017.

\section{B. KAJIAN LITERATUR}

\section{Teori Kebijakan Deviden}

Dalam Hartono (2013) teori yang berhubungan dengan kebijakan deviden antara lain :

\section{a) Irrelevance Theory}

Miller dan Modigliani menyebutkan bahwa deviden sifatnya adalah tidak relevan. Besar kecilnya deviden tidak mempengaruhi nilai perusahaan. Yang memepngaruhi nilai perusahaan adalah investasi yang ditanamkan.

\section{b) Tax Prefference Theory}

Litzenberger dan Ramaswamy menyebutkan bahwa oleh karena keuntungan deviden dan capital gain dikenakan pajak, tetapi para investor lebih menyukai capital gain karena dapat menunda pembayaran pajak.

\section{c) Bird in The Hand Theory}

Lintner, Gordon dan Batthacarya menjelaskan bahwa investor menyukai deviden yang tinggi daripada pendapatan modal, karena alasan utamanya adalah deviden lebih pasti daripada pendapatan modal. Devioden yang diterima seperti burung ditangan yang resikonya kecil.

\section{d) Residual Theory of Devidend}

Perusahaan memberikan dividen setelah investasi yang menguntungkan habis dibiayai. Setelah membiayai semua investasi yang menguntungkan, baru perusahaan membayar deviden kepada para investor.

\section{e) Clientele Effect Theory}

Kelompok investor yang hanya bergantung pada deviden, mungkin akan lebih menyukai pembayaran deviden yang tinggi. Kelompok sebaliknya lebih menyukai jika perusahaan menahan laba.

\section{f) Agency Theory}


Pemilik perusahaan membayar gaji karyawan atau agen untuk bertindak mendapatkan laba. Agen bertindak dalam kaitannya untuk menunjukkan kinerja kepada pemilik. Hubungan keduanya membentuk dua kepentingan. Kepentingan pemilik dan kepentingan agen. Dua kepentingan berbeda menimbulkan konflik agensi.

\section{g) Signalling Theory}

Dalam teori ini menunjukkan bahwa kenaikan dan penurunan dividen biasanya merupakan sinyal bagi para investor dalam meramalkan suatu penghasilan yang baik dan buruk di masa yang akan datang. Kenaikan dan penurunan deviden menunjukkan kinerja manajemen, sehingga memberikan sinyal kepada investor tentang baik dan buruknya kinerja manajemen.

\section{Deviden Kas}

Deviden kas merupakan alokasi laba untuk pemegang saham dalam bentuk aliran kas yang mengandung informasi kinerja manajemen. Deviden kas menurut Gittman, Lawrence (2009) adalah arus kas untuk pemegang saham serta memberikan informasi kinerja perusahaan saat ini dan masa yang akan datang. Wild, John J., K.R. Subramanyam, dan Robert F. Halsey (2008) mendefinisikan deviden kas sebagai distribusi kas kepada pemegang saham. Sementara menurut Van Horne dan Wachowicz (2007) menyatakan bahwa dividen merupakan rasio yang menentukan jumlah laba yang dapat ditahan dalam perusahaan sebagai sumber pendanaan.

\section{Investment Opportunity Set (IOS)}

Pengertian IOS lebih kepada sikap untuk menentukan pilihan dari sekian banyak pilihan investasi untuk menghasilkan return yang baik di masa yang akan datang, sehingga return yang baik mengakibatkan nilai pasar perusahaan lebih besar dari nilai bukunya yang pada akhirnya perusahaan mempunyai kesempatan untuk bertumbuh. Perusahaan akan selalu meningkatkan pertumbuhannya dengan berinvestasi. Menurut Suharli, Michell (2007), apabila kondisi perusahaan lebih baik, manajemen biasanya cenderung untuk memilih investasi baru, dibanding membayar deviden kas kepada para pemegang saham, bahkan untuk mengatasi masalah underinvestment. Perusahaan yang mengalami pertumbuhan lambat cenderung untuk membagikan deviden lebih tinggi untuk mengatasi overinvestment.

Ramadhan, Wiby Aqlia (2016), mendefinisikan IOS sebagai tingkat kesempatan perusahaan untuk investasi yang tersedia. Sedangkan menurut Kristanti, Farida Titik dan Fitrianingsih (2013), IOS adalah nilai perusahaan yang besarnya bergantung pada pengeluaran-pengeluaran investasi, yang diharapkan menghasilkan return lebih besar.

\section{Ukuran Perusahaan}

Ukuran perusahaan dintentukan dengan melihat total aset, bilamana total asetnya besar bisa dogolongkan ke dalam perusahaan besar begitupun sebaliknya. Sesuai dengan Sembiring, Christine Febrina (2018) yang menyatakan bahwa ukuran perusahaan dinyatakan dengan total aset, dimana dalam hal ini dapat menentukan posisi suatu perusahaan dalam menjalankan usahanya memperoleh laba.

\section{METODOLOGI PENELITIAN}

\section{Sample}

Populasi dalam peelitian ini adalah perusahaan LQ45. Dengan teknik purposive sampling dengan krieria sebagai berikut : (1) penelitian dilakukan terhadap perusahaan indeks LQ45 untuk periode 2015-2017 (2) perusahaan mampu membayar deviden kas selama periode 2015-2017 (3) laporan keuangan yang dibuat dengan mata uang rupiah (4) perusahaan membuat laporan keuangannya sesuai dengan variabel yang diteliti. Dengan 
kriteria tersebut di atas dari jumlah populasi 45 perusahaan didapatkan sampel sebanyak 15 perusahaan dengan periode penelitian 2015-2017. Data didapat sebanyak 45 data observasi.

\section{Definisi Operasional dan Pengukuran}

a) Variabel Dependen

Variabel dependen dalam penelitian ini adalah deviden kas (Y). Formula deviden kas sebagai berikut :

$$
\text { Deviden Kas = - - } \begin{aligned}
& ---------- \\
& \text { Jumlah Saham Beredar }
\end{aligned}
$$

\section{b) Variabel Independen}

1). Investment Opportunity Set

Variabel independen pertama (X1) adalah IOS. IOS merupakan peluang untuk memilih investasi agar bisa menghasilkan return tinggi. Laba yang didapat dinvestasikan untuk pertumbuhan perusahaan. Dalam penelitian ini formulasi IOS adalah berdasarkan Rasio Market Value to Book Value of Equity (MVEBVE). berikut:

Martazela, Ayu et al (2013), formula Market Value to Book Value of Equity sebagai

$$
\text { MVEBVE = }
$$

$$
\text { Jumlah saham beredar } \mathrm{x} \text { Harga penutupan saham }
$$

\section{2). Ukuran Perusahaan}

\section{Total Ekuitas}

Variabel independen kedua (X2) dalam penelitian ini adalah ukuran perusahaan. Ukuran perusahaan dapat diukur dengan total aset logaritma natural.

\section{Teknik Analisis Data}

Untuk menguji hipotesis menggunakan analisis linier berganda. Anlisis linier berganda berfungsi untuk menjelaskan hubungan variabel independen yang lebih satu terhadap variabel dependen. Sebelum menguji analisis regresi berganda terlebih dahulu diuji asumsi klasik untuk membuktikan apakah model regresi terdapat masalah normalitas, multikolinieritas, auitokorelasi serta heteroskedastisitas. Sedangkan model analsis yang dipakai adalah sebagai berikut :

Dimana

$$
\begin{array}{ll}
\qquad \mathrm{Y}=\alpha+(\beta 1 . \mathrm{X} 1)+(\beta 2 . \mathrm{X} 2)+\varepsilon \\
\mathrm{Y} & =\text { Deviden Kas } \\
\mathrm{X} 1 & =\text { Investment Opportunity Set }(I O S) \\
\mathrm{X} 2 & =\text { Ukuran Perusahaan } \\
\alpha & =\text { Konstanta } \\
\beta 1, \beta 2 & =\text { Koefisien Korelasi } \\
\varepsilon & =\text { Error }
\end{array}
$$

\section{HASIL DAN PEMBAHASAN}

\section{Analisis Deskriptif}

Tabel 4.1. Statistik Deskriptif

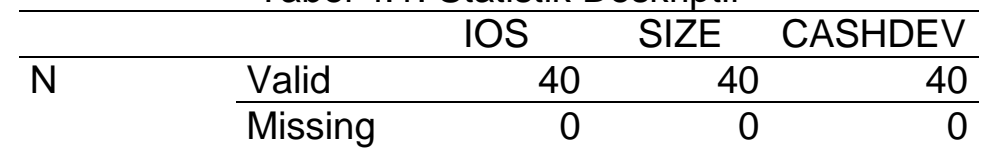




\begin{tabular}{|c|c|c|c|}
\hline Mean & 7,8505 & 1,56206 & 264,18 \\
\hline Median & 2,5400 & 1,65400 & 206,00 \\
\hline Mode & $1,15^{\mathrm{a}}$ &, $672^{a}$ & $120^{\mathrm{a}}$ \\
\hline Std. Deviation & 17,73272 &, 502185 & 256,379 \\
\hline Variance & 314,450 & ,252 & 65730,148 \\
\hline Minimum & 17 & 672 & 19 \\
\hline Maximum & 82,44 & 2,230 & 1375 \\
\hline Percentiles 25 & 1,5875 & 1,10669 & 120,00 \\
\hline 50 & 2,5400 & 1,65400 & 206,00 \\
\hline 75 & 4,8050 & 2,05317 & 306,50 \\
\hline
\end{tabular}

a. Multiple modes exist. The smallest value is shown

Dalam tabel 4.1. Nilai minimum Deviden Kas sebesar 19 yaitu PT. Kalbe Farma Tbk. Pada tahun 2015. Keadaan ini menunjukkan bahwa pembagian deviden kasnya kurang baik diantara perusahaan terindeks LQ45. Meskipun perusahaan mendapatkan laba besar namun pembagian devidennya kecil. Nilai maksimum variabel deviden kas adalah 1375 yaitu PT. Unilever Indonesia Tbk. PT. Unilever Indonesia Tbk. menunjukkan perusahaan mendapatkan laba besar dan memberikan deviden kas juga besar diantara perusahaan terindeks LQ45. Nilai sandar deviasi sebesar 256,379 dan nilai rat-rata sebesar 264,18. Nilai standar deviasi lebih kecil dibanding nilai rata-rata, 256,379 $<264,18$, jika demikian berarti rata-rata data deviden kas adalah dapat digunakan sebagai reprentasi dari keseluruhan data.

Hasil statistik pada tabel 4.1. untuk variabel IOS mempunyai nilai minimum sebesar 0,17, dari PT. Adaro Energy Tb. Pada tahun 2015. Hal ini mengindikasikan bahwa pembayaran deviden kasnya kurang baik diantara perusahaan yang terindeks LQ45 meskipun mendapatkan laba tinggi, tetapi deviden kas yang dibagikan rendah. Nilai IOS maksimum adalah sebesar 82,44 dari PT. Unilever Indonesia Tbk. pada tahun 2017. PT. Unilever Indonesia mendapatkan laba tinggi, perusahaan tetap memberikan deviden kas tinggi diantara perusahaan terindeks LQ45. Nilai rata-rata variabel IOS adalah sebesar 7,8505 dan nilai standar deviasinya adalah sebesar 17,73272. Nilai standar deviasi lebih besar dari nilai rata-rata, 17,73272 < 7,8505, menunjukkan bahwa rata-rata data IOS representasi kurang baik dari keseluruhan data.

Dalam tabel 4.1. nilai minimum untuk variabel ukuran perusahaan adalah sebesar 0,672 dari PT. Unilever Indonesia Tbk. pada tahun 2016, artinya perusahaan mempunyai aset terkecil diantara perusahaan terindeks LQ45. Nilai tertinggi untuk ukuran perusahaan adalah sebesar 2,230 adalah dari PT. Bank Mandiri (Persero) Tbk. pada tahun 2017. Pada tahun 2017 PT. Bank Mandiri (Persero) Tbk. mempunyai aset terbesar diantara perusahaan terindeks LQ45. Nilai rata-rata ukuran perusahaan adalah sebesar 1,56206 dan standar deviasi sebesar 0,502185, artinya nilai standar deviasi lebih kecil dari nilai rata-rata, 0,502185 < 1,56206, menunjukkan bahwa nilai rata-rata data ukuran perusahaan homogen atau dapat digunakan sebagai representasi dari keseluruhan data.

\section{Uji Asumsi Klasik}

a) Normalitas

Hasil perhitungan statistik dalam tabel 4.2. dari data 15 perusahaan adalah 45 data masih belum normal, setelah data outlier dbuang dan menjadi 40 data, maka data menjadi normal dengan Asymp. Sig. (2-tailed) dengan tingkat signifikansi sebesar 0,095, artinya nilai ini lebih besar dari signifikansi 0,05 sehingga $\mathrm{H} 0$ diterima dan $\mathrm{H} 1$ ditolak. $\mathrm{H} 0$ diterima berarti data berdistribusi normal.

Tabel 4.2. Uji Normalitas

One-Sample Kolmogorov-Smirnov Test

\section{Unstandardized}

Residual 


\begin{tabular}{llr} 
N & & 40 \\
\hline Normal Parameters & Mean & $-17,4940795$ \\
\cline { 2 - 3 } & Std. & 170,17351340 \\
& Deviation &, 128 \\
\hline Most Extreme & Absolute &, 128 \\
\cline { 2 - 3 } Differences & Positive &,- 079 \\
\cline { 2 - 3 } & Negative &, 128 \\
\hline Test Statistic & &, $095^{c}$ \\
\hline Asymp. Sig. (2-tailed) & & \\
\hline
\end{tabular}

\section{b) Multikolinieritas}

Tabel 4.3. menunjukkan bahwa variabel independen memiliki nilai tolerance mendekati 1 atau lebih besar dari 0,10, yaitu 0,757 dan nilai VIF diantara 0 dan 10, yaitu 1,321. Dapat disimpulkan antar variabel independen tidak terjadi multikolinieritas dalam model regresi.

Tabel 4.3. Uji Multikolinieritas

\begin{tabular}{|c|c|c|c|c|c|c|c|c|}
\hline \multirow[b]{2}{*}{ Mode } & & $\begin{array}{r}\text { Unstanc } \\
\text { Coeffi }\end{array}$ & $\begin{array}{l}\text { lardized } \\
\text { cients }\end{array}$ & \multirow{2}{*}{$\begin{array}{c}\begin{array}{c}\text { Standardiz } \\
\text { ed } \\
\text { Coefficient } \\
\text { s }\end{array} \\
\text { Beta }\end{array}$} & \multirow[b]{2}{*}{$\mathrm{t}$} & \multirow[b]{2}{*}{ Sig. } & \multicolumn{2}{|c|}{$\begin{array}{c}\text { Collinearity } \\
\text { Statistics }\end{array}$} \\
\hline & & B & Std. Error & & & & $\begin{array}{c}\text { Toleran } \\
\text { ce }\end{array}$ & VIF \\
\hline 1 & $\begin{array}{l}\text { (Consta } \\
\text { nt) }\end{array}$ & 152,568 & 110,956 & & 1,375 & ,177 & & \\
\hline & IOS & 11,062 & 1,812 & ,764 & 6,105 & ,000 & ,757 & 1,321 \\
\hline & SIZE & 16,575 & 63,925 & ,032 & ,259 & ,797 & ,757 & 1,321 \\
\hline
\end{tabular}

a. Dependent Variable: CASHDEV

\section{c) Autokorelasi}

Hasil uji autokorelasi dengan menggunakan syarat $\mathrm{dl}<\mathrm{dwh}<4$-du. Nilai DurbinWatson adalah 1,403. Sementara nilai dl dan du dihitung dengan melihat tabel durbin watson, $\mathrm{k}=3, \mathrm{n}=40$, sehingga nilai $\mathrm{dl}$ dan du didapat 1,3384 dan 1,6589. 4-du adalah 2,3241 , sehingga nilai $d w$ ada diantara $1,3384<1,403<2.3241$. Dengan demikian tidak terjadi autokorelasi.

Tabel. 4.4. Uji Autokorelasi

Model Summary

\begin{tabular}{|c|c|c|c|c|c|}
\hline Model & $\mathrm{R}$ & R Square & $\begin{array}{l}\text { Adjusted R } \\
\text { Square }\end{array}$ & $\begin{array}{l}\text { Std. Error of } \\
\text { the Estimate }\end{array}$ & $\begin{array}{l}\text { Durbin- } \\
\text { Watson }\end{array}$ \\
\hline 1 &, $749^{a}$ & ,561 & ,537 & 174,397 & 1,403 \\
\hline a. Pred & s: (Cor & stant), SIZE & IOS & & \\
\hline
\end{tabular}

\section{Uji Hipotesis dan Diskusi}

\section{a) Analisis Regresi Linier Berganda}

Penelitian ini menguji pengaruh Investment Opportunity Set (IOS) dan Ukuran Perusahaan terhadap Devidan Kas pada perusahaan yang terindeks LQ45 perode 20152017. Regresi Linier Berganda dapat dihasilkan berdasarkan pada tabel 4.5. sebagai berikut : 


$$
Y=152,568+(11,062 . X 1)+(16,575 . X 2)
$$
berikut :

Persamaan regresi linier berganda tersebut diatas dapat diinterpretasikan sebagai

1. a sebesar 152,568 srtinya apabila variabel independen, IOS dan ukuran perusahaan bernilai nol (0), maka variabel dependen Deviden Kas memiliki nilai 152,568 .

2. $\beta 1$ mempunyai nilai koefisien regresi positif 11,062 artinya jika IOS naik satu satuan, sementara ukuran perusahaan nilainya konstan, maka deviden kas naik sebesar 11,062 .

3. $\quad$ 2 mempunyai nilai koefisien regresi sebesar positif 16,575 artinya jika ukuran perusahaan naik satu satuan, sementara IOS konstan, maka deviden kas naik sebesar 16,575 .

b) Uji Simultan (Uji F)

Tabel 4.5. Uji F (Uji Simultan)

ANOVA $^{\mathrm{a}}$

\begin{tabular}{|c|c|c|c|c|c|c|}
\hline & & $\begin{array}{l}\text { Sum of } \\
\text { Squares }\end{array}$ & df & $\begin{array}{l}\text { Mean } \\
\text { Square }\end{array}$ & $\mathrm{F}$ & Sig. \\
\hline \multirow[t]{3}{*}{1} & $\begin{array}{l}\text { Regressio } \\
n\end{array}$ & $\begin{array}{r}1438144,49 \\
0\end{array}$ & 2 & 719072,245 & 23,643 &, $000^{\mathrm{b}}$ \\
\hline & Residual & $\begin{array}{r}1125331,28 \\
5\end{array}$ & 37 & 30414,359 & & \\
\hline & Total & $\begin{array}{r}2563475,77 \\
5 \\
\end{array}$ & 39 & & & \\
\hline
\end{tabular}

a. Dependent Variable: CASHDEV

b. Predictors: (Constant), SIZE, IOS

Pengujian ini adalah untuk mengetahui pengaruh variabel IOS dan ukuran perusahaan berpengaruh secara simultan. Dengan tingkat signifikansi $5 \%$ derajat kebebasan df1 $=3$ dan df2 $=40$, maka tabel didatkan $F(3,40)=2,839$. Perhitungan diperoleh $\mathrm{F}$ sebesar 232,643. $\mathrm{F}$ hitung lebih besar dibanding dengan $\mathrm{F}$ dalam tabel, yaitu $232,643>2,839$ sehingga $\mathrm{HO}$ ditolak. Tingkat signifikansi (sig) hitung adalah 0,000 , lebih kecil dari 0,05 , yaitu $0,000<0,05$, maka keputusannya $\mathrm{HO}$ ditolak, berarti secara simultan terdapat pengaruh antara IOS dan ukuran perusahaan terhadap deviden kas pada perusahaan yang terindeks LQ45 periode 2015-2017.

\section{c) Uji t (Uji Pasrsial)}

\section{1). Pengaruh IOS Terhadap Deviden Kas}

Dalam penelitian ini diketahui bahwa $n=40$ pada tingkat signifikansi $5 \%$. Hasil penelitian pada regresi berganda diperoleh nilai t sebesar 6,105 , sedangkan t dalam tabel sebesar 2,023. Pengujian t test dengan menggunakan uji dua sisi, hasilnya adalah t hitung berada pada daerah $\mathrm{H} 0$ ditolak dan $\mathrm{Ha}$ diterima. Sedangkan jika dilihat dari tingkat signifikansinya $0,000<0,05$, maka keputusannya juga menolak $\mathrm{H} 0$. Hasil ini menunjukkan bahwa IOS berpengaruh signifikan terhadap deviden kas pada perusahaan terindeks LQ45 periode 2015-2017.

\section{2). Pengaruh Ukuran Perusahaan Terhadap Deviden Kas}

Hasil yang didapat dalam penelitian regresi berganda ini nilai $t$ adalah 0,259 , sedangkan t dalam tabel adalah sebesar 2,023. Diuji dengan menggunakan uji dua sisi ternyata $\mathrm{t}$ hitung berada diantara daerah $\mathrm{HO}$ diterima dan $\mathrm{Ha}$ ditolak. Hasilnya menunjukkan bahwa ukuran perusahaan tidak berpengaruh signifikan terhadap deviden 
kas. Dilihat dari perhitungan signifikansinya menunjukkan $0,797>0,05$, maka keputusannya adalah $\mathrm{H} 0$ juga diterima. Hasil ini menunjukkan ukuran perusahaan tidak berpengaruh signifikan terhadap deviden kas pada perusahaan yang terindeks LQ45 periode 2015-2017.

\begin{tabular}{|c|c|c|c|c|c|c|c|}
\hline \multicolumn{8}{|c|}{$\begin{array}{l}\text { Tabel 4.6. Uji Hipotesis } \\
\text { Coefficients }^{\mathbf{a}}\end{array}$} \\
\hline \multirow[b]{3}{*}{ Model } & \multirow{2}{*}{\multicolumn{2}{|c|}{$\begin{array}{l}\text { Unstandardized } \\
\text { Coefficients }\end{array}$}} & \multirow{3}{*}{$\begin{array}{c}\begin{array}{c}\text { Standardiz } \\
\text { ed } \\
\text { Coefficient } \\
\text { s }\end{array} \\
\text { Beta }\end{array}$} & \multirow[b]{3}{*}{$\mathrm{t}$} & \multirow[b]{3}{*}{ Sig. } & \multirow{2}{*}{\multicolumn{2}{|c|}{$\begin{array}{l}\text { Collinearity } \\
\text { Statistics }\end{array}$}} \\
\hline & & & & & & & \\
\hline & B & Std. Error & & & & $\begin{array}{l}\text { Toleran } \\
\text { ce }\end{array}$ & VIF \\
\hline $\begin{array}{l}1 \text { (Constan } \\
\text { t) }\end{array}$ & 152,568 & 110,956 & & 1,375 & , 177 & & \\
\hline IOS & 11,062 & 1,812 & ,764 & 6,105 & ,000 & ,757 & 1,321 \\
\hline SIZE & 16,575 & 63,925 & ,032 & ,259 & ,797 & ,757 & 1,321 \\
\hline
\end{tabular}

\section{d) Uji Koefisien Determinasi $\left(\mathbf{R}^{2}\right)$}

Dalam tabel 4.7. nilai koefisien determinasi (R2) pada penelitian ini adalah 0,537 atau sebesar $53,7 \%$ yang menunjukkan bahwa deviden kas dipengaruhi oleh 2 variabel independen, IOS dan ukuran perusahaan, sisanya $42,3 \%$ dipengaruhi variabel lain yang belum diteliti dalam penelitian ini.

4.7. Uji Koefisien Determinasi

\begin{tabular}{lrrrrr}
\hline Model & $\mathrm{R}$ & $\mathrm{R}$ Square & $\begin{array}{c}\text { Adjusted R } \\
\text { Square }\end{array}$ & $\begin{array}{c}\text { Std. Error of } \\
\text { the Estimate }\end{array}$ & $\begin{array}{c}\text { Durbin- } \\
\text { Watson }\end{array}$ \\
\hline 1 &, $749^{\mathrm{a}}$ &, 561 &, 537 & 174,397 & 1,403 \\
\hline a. Predictors: (Constant), SIZE, IOS & & & \\
\hline b. Dependent Variable: CASHDEV
\end{tabular}

\section{e) Pembahasan}

\section{1). Investment Opportunity Set (IOS) Berpengaruh Terhadap Deviden Kas}

Hipotesis 1 menyatakan bahwa investment opportunity set (IOS) berpengaruh negatif terhadap deviden kas. Hasil pengujian pada penelitian ini menunjukkan bahwa pada signifikansi 5\% ternyata IOS berpengaruh positif dengan demikian Hipotesis 1 ditolak pada tingkat keyakinan 95\%. Koefisien regresi IOS terhadap deviden kas menunjukkan arah positif yang berarti bahwa perusahaan yang mempunyai kesempatan investasi yang tinggi akan memberikan deviden yang tinggi pula. Hasil penelitian ini memberikan gambaran bahwa pada perusahaan-perusahaan yang terindeks pada LQ45, IOS mempengaruhi deviden kas terbalik. Artinya perusahaan-perusahaan terindeks LQ45 mempunyai kesempatan investasi yang tinggi dengan labanya, juga akan memberikan deviden kas yang tinggi kepada para investor.

Hasil penelitian ini secara teoritis tidak mendukung hipotesis yang menyatakan perusahaan yang berkesempatan untuk tumbuh dan terus investasi akan lebih besar mengalokasikan keuntungannya untuk investasi hingga pembayaran deviden kasnya kecil.

\section{2). Ukuran Perusahaan Berpengaruh Terhadap Deviden Kas}

Perusahaan besar dengan nilai aset yang besar cenderung dalam memberikan pembayaran deviden lebih besar dibanding perusahaan yang kecil. Perusahaan besar lebih lengkap sumber dayanya, sehingga bisa lebih memanfaatkan kesempatan, kepercayaan dan fleksibilitasnya dalam pasar modal. Dalam penelitian ini ukuran perusahaan diukur dengan rasio Logaritma Natural (Ln) dari Total Aset. Nilai signifikansi variabel ukuran perusahaan sebesar 0,797 lebih besar dari 0,05. Ini menunjukkan bahwa 
ukuran perusahaan tidak berpengaruh terhadap deviden kas pada perusahaan-perusahaan yang terindeks LQ45. Berdasarkan hasil analisis deskriptif menunjukkan rata-rata variabel ukuran perusahaan mengalami kenaikan dan penurunan tidak mempengaruhi sikap perusahaan dalam memberikan deviden kepada para investor. Ketika perusahaan menunjukkan ukuran perusahaan meningkat, pembayaran deviden lebih cenderung tetap diberikan. Begitu pula sebaliknya ketika variabel ukuran perusahaan perusahaan menurun, perusahaan tetap memberikan deviden kas kepada para pemegang saham. Dalam perusahaan yang terindeks LQ45 adalah perusahaan yang manajemennya lebih kuat sehingga, selalu memberikan kepastian kepada para pemegang saham, baik ketika ukuran perusahaan meningkat ataupun sebaliknya.

\section{E. SIMPULAN}

Penelitian ini menghasilkan kesimpulan ;

1. Invetment Opportunity Set (IOS) yang cenderung meningkat berpengaruh terhadap deviden kas pada perusahaan-perusahaan yang terindeks LQ45. Dimana IOS mempunyai arah hubungan yang positif, artinya ketika IOS meningkat, deviden kas yang diberikan kepada para pemegang saham pun meningkat. Hasil penelitian ini tidak mendukung hipotesis bahwa IOS meningkat mengakibatkan pembayaran deviden menurun.

2. Dari hasil penelitian ditemukan bahwa ukuran perusahaan, yang juga cenderung meningkat, tidak berpengaruh terhadap deviden kas pada perusahaan-perusahaan terindeks LQ45. Dengan signifikansi 5\% dan tingkat keyakinan 95\% ukuran perusahaan tidak berpengaruh terhadap pembayaran deviden kas. Perusahaan terindeks LQ45, cenderung disebut perusaahn besar dengan total aset lebih besar dibanding perusahaan di luar LQ45, selalu memberikan kepastian terkait deviden kas kepada para investor atau pemegang sahamnya. 


\section{DAFTAR PUSTAKA}

Ardyatama. 2018. Pengaruh Profitabilitas, Ukuran Perusahaan, Leverage, Dan Arus Kas Bebas Terhadap Kebijakan Dividen. Skripsi. FEB Universitas Lampung.

Baharianti, Septi. 2018. Pengaruh Profitabilitas, Leverage, Ukuran Perusahaan, dan Likuiditasterhadap Kebijakan Dividen Tunai Pada Perusahaan Manufaktur Yang Terdaftar Di BEI. Skripsi. STIE Perbanas Surabaya.

Darmadji, Tjiptono dan Hendy M. Fakhruddin. 2012. Pasar Modal Indonesia Edisi 3. Jakarta. Penerbit Salemba Empat.

Dewi, Dian Masita. 2016. Pengaruh Likuiditas, Leverage, Ukuran Perusahaan Terhadap Kebijakan Dividen Tunai Dengan Profitabilitas Sebagai Variabel Intervening Jurnal Bisnis dan Ekonomi (JBE), Maret 2016, Hal. 12 - 19 Vol. 23, No. 1, ISSN: 14123126.

Dhestiani, Rosyida Putri., Patricia Dhiana Paramita Dan Hartono. 2018. Pengaruh Profitabilitas Dan Free Cash Flow Terhadap Cash Dividen Dengan Likuiditas Sebagai Variabel Moderatig Pada Perusahaan Manufaktur Sektor Industri Barang Konsumsi Yag Terdaftar Pada Bei Tahun 2012-2016. Journal of Accounting 2018. FE Universitas Pandanaran Semarang.

Gitman, Lawrence. 2009. Principles of Manajerial Finance. United States: Pearson Addison Wesley.

Hartono, Jogiyanto. 2013. Teori Portofolio dan Analisis Investasi Edisi Kedelapan. Yogyakarta. Penerbit BPFE Universitas Gadjah Mada.

Herlambang, Arif., Putu Anom Mahadwartha danStefan Adi Christianto. The Effect Stock Liquidity To Cash Dividend For Non-Finance Company Listed On Bei In 2012 - 2016. Journal of Management and Business, Vol. 16, No.2(September 2017).

Horne, Van dan Wachowicz. 2007. Fundamentals of Financial Management, PrinsipPrinsip Manajemen Keuangan. Jakarta : Salemba Empat.

Jhon J. Wild., K.R. Subramanyam., dan Robert F. Halsey. 2007. Financial Statement Analysis. 9 th edition. McGraw-Hill.

Kadim, A., \& Sunardi, N. (2019, May). Eviews Analysis; Determinan Tourism, Restaurant and Hotel Company's Soundness and Performance. In Proceeding Interuniversity Forum for Strengthening Academic Competency (Vol. 1, No. 1, pp. 332-340).

Kristanti, Farida Titik Dan Fitrianingsih. 2013. The Effect Of Profitability And Investment Opportunity Set On Cash Dividend With Liquidity As Moderate Variables (Studied At Kompas 100 That Listed On Jsx In 2008-2012 Period). Jurnal Manajemen Bisnis Indonesia Volume 1, Nomor 1, Oktober 2013.

Martazela, Ayu, Fenny Marietza dan Pratana Puspa Midiastuty. 2013. Effect of Profitability and Investment Opportunity Set of Cash Dividen Policy with the Liquidity and Leverage. Journal of Accounting and Finance, Universitas Bengkulu.

Nurhayati, Mafizatun. Profitabilitas, Likuiditas Dan Ukuran Perusahaan Pengaruhnya Terhadap Kebijakan Dividen Dan Nilai Perusahaan Sektor Non Jasa. Jurnal Keuangan dan Bisnis, Vol. 5, No. 2, Juli 2013.

Puspitawati, Lilis dan Reza Nur Arifin. Pengaruh Profitabilitas (Return On Invesment) Dan Invesment Opportunity Set (los) Terhadap Dividen Kas (Studi Kasus Pada Perusahaan Asuransi Yang Terdaftar Di Bursa Efek Indonesia Periode 2008-2011).

Ramadhan, Wiby Aqlia. 2016. Analisis Pengaruh Free Cash Flow, Investment Opportunity Set, Dan Sales Growth Terhadap Dividend Policy Pada Perusahaan Manufaktur Yang Terdaftar di Bursa Efek Indonesia.Skripsi.Universitas Negeri Yogyakarta. 
Santoso, Edwin. 2018.40 Saham Terbaik, Updated Version. Jakarta. Elex Media Komputindo.

Sari, Ni Luh Putu Puspita dan I Ketut Budiartha. 2016. Pengaruh Investment Opportunity Set (los) Pada Kebijakan Dividen Tunai Dengan Umur Perusahaan Sebagai Variabel Pemoderasi. E-Jurnal Ekonomi dan Bisnis Universitas Udayana 5.5 (2016) : 13351358. ISSN : 2337-3067.

Sarmento, Jaquelina N. L., Kertahadi dan Nila Firdausi Nuzula. 2014. The Effects Of Investment Opportunity Set (los) And Corporate Financing On Dividend Payout Policy (A Study On Automotive And Components Companies Listed In Indonesia Stock Exchange Period 2009-2011). Jurnal Administrasi Bisnis (JAB)Vol. 13 No. 2 August 2014.

Sembiring, Christine Febrina. 2018. Pengaruh Leverage, Likuiditas, Profitabilitas dan Ukuran Perusahaan terhadap Kebijakan Dividen Perusahaan Properti dan Real Estate yang terdaftar di Bursa Efek Indonesia Periode 2013-2016. Skripsi. FEB Universitas Sumateru Utara.

Sugiyono. 2014. Statistika Untuk Penelitian. Bandung. Penerbit Alfabeta.

Suharli, Michell. 2007. Pengaruh Profitability dan Investment Opportunity Set Terhadap Kebijakan Dividen Tunai dengan Likuiditas Sebagai Variabel Penguat (Studi pada Perusahaan yang Terdaftar di Bursa Efek Jakarta Periode 2002-2003). Jurnal Akuntansi dan Keuangan, Vol. 9, No. 1, Mei 2007: 9-17.

Sukamulja, Sukmawati. 2017. Pengantar Pemodelan Keuangan dan Analisis Pasar Modal. Yogyakarta. Penerbot BPFE Universitas Gadjah Mada.

Sunardi, N. (2017). Determinan Kebijakan Utang Serta Implikasinya terhadap Kinerja Perusahaan (Perusahaan yang tergabung dalam indeks LQ. 45 yang terdaftar di Bursa Efek Indonesia Tahun 2011-2015). Jurnal Sekuritas, 1(1).

Sunardi, N. (2017). Determinan Kebijakan Utang Serta Implikasinya terhadap Kinerja Perusahaan (Perusahaan yang tergabung dalam indeks LQ. 45 yang terdaftar di Bursa Efek Indonesia Tahun 2011-2015). Jurnal Sekuritas, 1(1).

Sunardi, N. (2017). Pengaruh Profitabilitas, Firm Size, Risiko Bisnis, Asset Growth, Leverage, Kebijakan Dividen Terhadap Institutional Ownership (Perusahaan Property \& Real Estate yang terdaftar di Bursa Efek Indonesia Tahun 2011-2014). INOVASI, 2(2).

Sunardi, N., \& Sasmita, A. S. (2019). Pengaruh Likuiditas, Leverage Dan Growth Terhadap Kinerja Industri Makanan Dan Minuman Yang Tercatat Di Indonesia Stock Exchange Selama Periode Tahun 2011-2015. Jurnal SEKURITAS (Saham, Ekonomi, Keuangan dan Investasi), 2(2), 81-97. 